\title{
Researcher's Role in Forest Sector Development
}

\section{Vitor Augusto Cordeiro Milagres*}

Master's Degree in Forest Engineering, Federal University of Lavras, Brazil

*Corresponding Author: Vitor Augusto Cordeiro Milagres, Master's Degree

in Forest Engineering, Federal University of Lavras, Brazil.

DOI: $10.31080 /$ ASAG.2020.04.0788
Received: November 26, 2019

Published: February 01, 2020

(C) All rights are reserved by Vitor Augusto

Cordeiro Milagres.
With regard to agribusiness, one of the areas that is constantly developing is the segment of trees grown for industrial purposes, especially Eucalyptus and Pine. Demand for pulp and paper, wood panels and laminate floors, solid wood and charcoal-fired products stands out. Only in Brazil, for example, productivity jumped from $25 \mathrm{~m}^{3}$.ha ${ }^{-1}$.year-1 in 1990 to $36 \mathrm{~m}^{3} \cdot \mathrm{ha}^{-1}$.year ${ }^{-1}$ in 2018, an increase of $44 \%$, according to data from the Brazilian Tree Industry (IBÁ).

Part of this steady growth is due to innovations and continuous advances in forest management, silvicultural practices, operational efficiency and genetic improvement. In addition, none of this could happen without investment in research and development. Researchers from around the world have emphasized process and product improvement and optimization, making forest stands more productive, sustainable and cost-effective!

Historically, the strong contribution of academic professionals in the development of the forest sector has been known, but one cannot forget and underestimate the participation of private sector researchers, individually, but also through cooperative programs. Several of them seek to integrate processes and results from similar lines of research, bringing greater applicability to new knowledge and taking information to associated companies more quickly.

Examples of this are studies on forest fertilization and nutrition. Fertilizers can be responsible for up to $40 \%$ of the cost of implantation or reform of a new plantation. However, research results in the private sector show that it is possible to reduce the spread of fertilization, applying mostly part of the fertilizers in planting fertilization, thus reducing operating costs and inputs for maintaining a forest.

Another example is the advances in soil preparation. Since replacing harrowing and plowing for minimum tillage, forest residues such as leaves, twigs and litter have remained on the surface of the soil. These have helped to reduce erosion processes, improving nutrient cycling in soils and helping to control weed competition. With the advent of georeferencing systems, it was still possible to control the depth of subsoiling and the amount of nutrients applied to the furrow, as well as the realignment of the planting lines.
Private sector interaction, cooperative programs, and universities need to be constant and ever closer. As for universities, it is important to ask the following question: What is the demand from society and companies for the newly graduated engineers? How should I prepare them to be efficient and quality researchers?

Challenges and concerns will continue: climate change, the advent of new pests and diseases, macro and microeconomic scenarios. However, it is important "to be on the ball". Researchers have had, have and will always have a prominent role in the development of agribusiness.

\section{Assets from publication with us}

- Prompt Acknowledgement after receiving the article

- Thorough Double blinded peer review

- Rapid Publication

- Issue of Publication Certificate

- High visibility of your Published work

Website: www.actascientific.com/

Submit Article: www.actascientific.com/submission.php Email us: editor@actascientific.com

Contact us: +919182824667 